\title{
Vegetative and productive performance of two soybean cultivars at different plant densities
}

\author{
Gustavo Lourenço Bomtempo ${ }^{1}$, Éder Matsuo ${ }^{2, *}$ (]) and Mario do Carmo Oda ${ }^{3}[\mathbb{C}$ \\ ${ }^{1}$ Agrarian Sciences Institute, Federal University of Viçosa - Rio Paranaíba Campus, Rio Paranaíba, MG, Brazil. \\ ${ }^{2}$ Technological and Exact Sciences Institute, Federal University of Viçosa, Rio Paranaíba Campus, Biostatistics Laboratory, \\ Highway MG 230, Km 7, PO Box 22, CEP 38810-000, Rio Paranaiba, MG, Brazil. ${ }^{3}$ Researcher, TMG - Tropical \\ Melhoramento \& Genética, Highway PR 445, Km 87 S/N, Lote 247, Gleba Jacutinga, CEP 86183-600, Cambé, PR, Brazil. \\ *Corresponding author, E-mail: edermatsuo@ufv.br
}

\begin{abstract}
The spatial arrangement and plant population have been highlighted as fundamental tools for increasing productivity. The objective was to evaluate the vegetative and productive performance of two soybean cultivars at different plant densities. Seeds of soybean cultivars (TMG 7063 IPRO and BS 2606 IPRO), recommended for the Alto Paranaíba region in the state Minas Gerais, were used and sown at seven different densities $\left(8,10,12,14,16,18\right.$ and 20 plants meter $^{-1}$, equivalent to $160,200,240,280,280,320,360$ and 400 thousand plants hectare ${ }^{-1}$, where they were evaluated in the development stages R1 (plant height) and R8 (height of the insertion of the first pod, plant height, number of nodes, number of branches, productivity per plant and productivity per hectare). The experiment was set up according to a randomized block design, in the factorial scheme $A \times B$, being factor $A$ composed by the cultivars and factor $B$ by plant densities with three repetitions (blocks). Increased plant population resulted in greater first pod insertion height and final plant height, fewer nodes and branches and the average yield per hectare increased linearly, with the TMG 7063 IPRO cultivar being more productive under these conditions ( 52.7 bags of $60 \mathrm{~kg}$ per hectare).
\end{abstract}

Keywords: Glycine max, densification, interaction, row spacing, spatial arrangements, plant architecture.

\section{INTRODUCTION}

The soybean (Glycine max (L.) Merr.) crop has relevance in Brazil, being the main Brazilian agricultural commodity. In this context, many producers have sought alternatives to increase their productivity (Tavares, Correia, Sousa, Riquetti, \& Silva, 2019). Most soybean cultivars have characteristics of high plasticity, which is the ability to adapt to environmental conditions and management, through changes in morphology and yield components (Ferreira-Junior, Espindola, Gonçalves, \& Lopes, 2010). This is particularity related to adaptation to altitude, latitude, soil fertility, sowing season, plant population, and different row spacing (Oda et al., 2015; Soares, Sediyama, \& Matsuo, 2020).

Achieving maximum profitability in a commercial soybean crop is the main objective of producers, and for this, along with favorable weather, various management techniques are employed. Among these techniques we can highlight the control of insects, diseases and weeds, the conservationist preparation of the soil, the efficient use of correctives and fertilizers, the choice of cultivars best adapted to the region, good quality seeds and the spatial arrangement of plants (Cruz, Sena-Junior, Santos, Lunezzo, \& Machado, 2016). The association of spatial arrangements and plant population have highlighted as a potential tool for increasing productivity (Brachtvogel, Pereira, Cruz, \& Bicudo, 2009).

The sowing density besides determining the arrangement of plants in the environment where it is located may influence the growth of soybean plants (Martins et al., 1999). Thus, the sowing density interferes in the inter and intra-specific competition for soil resources, especially for light, water and nutrients, besides causing morpho-physiological changes in the plants, such as height and engraftment (Argenta, Silva, \& Sangoi, 2001). In addition, it can affect the speed of closure between the rows (Heiffig, Câmara, Marques, Pedroso, \& Piedade, 2006; Silva, Petter, Lima, \& Andrade, 2013), the production of phytomass and soil cover by the plants (Cox \& Cherney, 2011), plant architecture (Pires, Costa, \& Thomas, 1998), disease severity (Lima, Alvarez, Theodoro, Bavaresco, \& Silva, 2012) and lodging (Balbinot-Junior, 2012).

Manuscripts that report studies involving productivity suggest that the soybean culture was able to withstand large population reductions without significant losses in productivity and this ability is influenced 
by the cultivar (Vazquez, Carvalho, \& Borba, 2008), that increased sowing density causes lower phytomass accumulation and soybean grain production per individual, a fact compensated by the larger number of plants, not affecting grain yield in the cultivar BRS 359 RR (Procópio, Balbinot-Junior, Debiasi, Santos, \& Panison, 2013). Thus, the objective was to evaluate the vegetative and productive performance of two soybean cultivars at different plant densities.

\section{MATERIALS AND METHODS}

The experiment was conducted under field conditions in the experimental area of the Federal University of Viçosa - Rio Paranaíba Campus (Latitude: $19^{\circ} 11^{\prime} 39^{\prime \prime}$ S, Longitude: 46 14' 37" W), in the 2019/2020 crop season, with planting on October 24, 2019, and harvest of the experimental plots on February 14, 2020. The cultivation site is at an altitude of 1,073 $\mathrm{m}$ and has a predominant Cwa climate, according to the KöppenGeiger classification, which is characterized by a dry season and a well-defined rainy period that occurs between October and March (Figure 1).

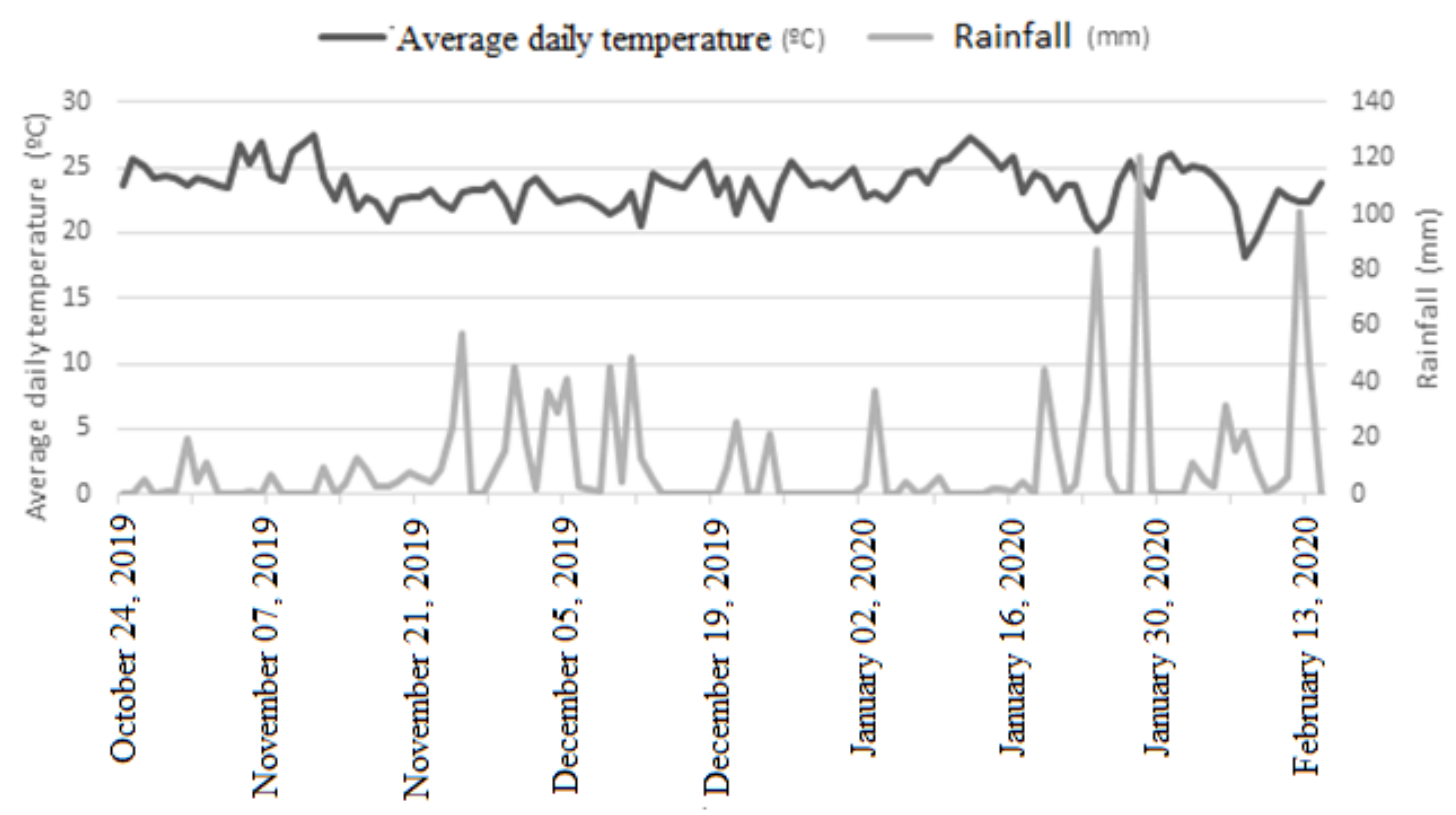

Figure 1. Rainfall and average daily temperature during the experiment in Rio Paranaíba, MG.

Source: Cooperativa Regional de Cafeicultores em Guaxupé Ltda (COOXUPÉ) (2020).

The soil of the area is classified as Red-Yellow Latosol with a very clayey texture (Empresa Brasileira de Pesquisa Agropecuária [EMBRAPA], 2013). For soil preparation, two harrow operations were performed, and a fertilizer spreader was used to perform the planting fertilization, applying $250 \mathrm{~kg} \mathrm{ha}^{-1}$ of NPK 8-28-16 based on soil analysis (Table 1).

Seeds of soybean cultivars (TMG 7063 IPRO and BS 2606 IPRO) (Table 2), recommended for the Alto Paranaíba region in Minas Gerais, were sown at seven different densities $(8,10,12,14,16,18$ and 20 plants per meter, equivalent to, respectively, 160, 200, 240, 280,320, 360 and 400 thousand plants per hectare), in $5.0 \mathrm{~m}$ long by $2.0 \mathrm{~m}$ wide plots. That is, each plot (experimental unit) was composed of four rows $5.0 \mathrm{~m}$ long $\mathrm{x}$ $0.5 \mathrm{~m}$ wide between the rows. Two central rows were considered for evaluation, disregarding $0.5 \mathrm{~m}$ of border, totaling $4 \mathrm{~m}^{2}$ of usable area.

Sowing was done manually, considering $80 \%$ of germination. The plants were thinned, with the help of previously marked wooden rulers, when the plants reached the V1 stage (Fehr \& Caviness, 1977) to the exact number of plants $\mathrm{m}^{-1}$ pre-defined for each density. Ten random plants per plot were evaluated for the characters listed below:

At the R1 developmental stage (Fehr \& Caviness, 1977): plant height, in centimeters, from the soil surface to the end of the main stem;

At the R8 development stage (Fehr \& Caviness, 1977): height of the first pod insertion, in centimeters, from the soil surface to the node of first pod insertion;

Plant height, in centimeters, from the soil surface to the end of the main stem; 
Number of nodes, counted from the cotyledonary node of the main stem;

Number of branches;

Yield per plant, in grams per plant $\left(\mathrm{g} \mathrm{pl}^{-1}\right)$; and

Grain yield, in $60 \mathrm{~kg}$ bags per hectare (bg ha-1).

Table 1. Soil analysis of the area.

\begin{tabular}{|c|c|c|c|c|c|c|c|c|}
\hline \multicolumn{2}{|c|}{$\mathrm{pH}$} & $P($ rem) & $\mathrm{S}-\mathrm{SO}_{4}$ & K & $\mathrm{Ca}$ & $\mathrm{Mg}$ & Al & \multirow{2}{*}{ M.O. } \\
\hline $\mathrm{H}_{2} \mathrm{O}$ & $\mathrm{CaCl}_{2}$ & \multicolumn{2}{|c|}{$\mathrm{mg} \mathrm{dm^{-3 }}(\mathrm{ppm})$} & \multicolumn{4}{|c|}{$\mathrm{cmol}_{\mathrm{c}} \mathrm{dm}^{-3}$} & \\
\hline 5.8 & 4.9 & 5.7 & 11.0 & 0.19 & 2.4 & 0.5 & 0.0 & 30.0 \\
\hline SB & $\mathrm{t}$ & $T$ & \multirow{2}{*}{$\mathrm{V}_{\%}$} & B & $\mathrm{Cu}$ & $\mathrm{Fe}$ & $\mathrm{Mn}$ & $\mathrm{Zn}$ \\
\hline \multicolumn{3}{|c|}{$\mathrm{cmol}_{\mathrm{c}} \mathrm{dm}^{-3}$} & & \multicolumn{5}{|c|}{$\mathrm{mg} \mathrm{dm^{-3 } ( p p m )}$} \\
\hline 3.09 & 3.09 & 8.59 & 36 & 0.14 & 1.2 & 23 & 0.8 & 1.5 \\
\hline
\end{tabular}

Table 2. Cultivars and their respective characteristics.

\begin{tabular}{ccclc}
\hline Cultivar & Maturity Group & Growth type & Cycle & Population per hectare \\
\hline TMG 7063 IPRO & 7.0 & Indeterminate & Early & 267 a 289 thousand \\
BS 2606 IPRO & 6.0 & Indeterminate & Early & 250 a 300 thousand \\
\hline
\end{tabular}

Source: Tropical Melhoramento \& Genética (TMG) (2021) and BASF (2021).

In order to standardize the yields at a moisture content of $13 \%$, the grains were weighed on an analytical balance (wet grain weight), after this first weighing they were taken to an oven and kept at 105 o C for 24 hours to reduce moisture, when they were removed, they were weighed again (dry grain weight) and then the moisture content was standardized at $13 \%$, according to the official method for determining moisture content, established by the Ministry of Agriculture, Livestock and Supply (Ministério da Agricultura, Pecuária e Abastecimento [MAPA], 2009).

$$
\begin{array}{ll}
\text { \% of humidity }(\mathrm{U})=\frac{100(\mathrm{P}-\mathrm{p})}{\mathrm{P}-\mathrm{t}} & \begin{array}{l}
\mathrm{P}=\text { initial weight (moist seed) } \\
\mathrm{p}=\text { final weight (dry seed) } \\
\mathrm{t}=\text { tara }
\end{array}
\end{array}
$$

The final weight of the sample was determined according to the formula:

Where:

$$
\mathrm{FW}=\frac{\mathrm{IW}(100-\mathrm{IH})}{(100-\mathrm{HS})} \quad \begin{aligned}
& \mathrm{FW}=\text { final weight of the sample } \\
& \mathrm{IW}=\text { initial weight of the sample } \\
& \mathrm{IH}=\text { initial humidity of the sample, in percentage. } \\
& \mathrm{HS}=\text { humidity of the sample }(13 \%)
\end{aligned}
$$

The experiment was set up according to a randomized block design, in an $\mathrm{A} \times \mathrm{B}$ factorial scheme, where factor A was composed of the cultivars and factor B was composed of the plant densities, with three 
repetitions (blocks). Each experimental unit was given by the average of the plants evaluated in each plot. The results were submitted to variance analysis, where the cultivar factor was evaluated by Tukey's Test and the plant density factor was evaluated by regression analysis. Statistical analyses considering $5 \%$ significance were performed in the Biostatistics Laboratory using the R Program (R Core Team, 2019).

\section{RESULTS AND DISCUSSION}

The plant height, evaluated at the R1 stage, depends simultaneously on the cultivars and plant densities, in other words, a significant effect was identified for the interaction cultivars vs densities and not significant for the isolated effects of cultivars and densities (Table 3 ). In the unfolding of the interaction cultivars vs densities, the cultivars (TMG 7063 IPRO and BS 2606 IPRO) did not differ regarding plant height when analyzing the behavior of different densities (Table 4).

Table 3. Summary of variance analysis of plant height obtained at the stage of development R1 (APR1), in $\mathrm{cm}$, height of insertion of the first pod (APV), in centimeters, final plant height (ATF), in centimeters, number of nodes (NN), number of branches (NR), productivity per plant (PF13), in g, and productivity, in $60 \mathrm{~kg}$ bags per ha (PFHA) obtained at the R8 development stage in 2 soybean cultivars and 7 plant densities (Densities), under field conditions, Rio Paranaíba-MG.

\begin{tabular}{ccccccccc}
\hline \multirow{2}{*}{ FV } & \multirow{2}{*}{ GL } & \multicolumn{7}{c}{ Mean Square $^{1}$} \\
\cline { 3 - 8 } & & APR1 & APV & ATF & NN & NR & PF13 & PFHA \\
\hline Block & & & & & & & \\
Cultivar & 2 & 2.828 & 5.664 & 57.20 & 1.700 & 0.401 & 4.68 & 37.10 \\
(C) & 1 & $14.408^{\text {ns }}$ & $2.171^{\text {ns }}$ & $1.27^{\text {ns }}$ & $57.634^{* *}$ & $9.619^{* *}$ & $25.92^{\text {ns }}$ & $679.81^{*}$ \\
Density & 6 & $2.965^{\text {ns }}$ & $10.644^{* *}$ & $324.69^{* *}$ & $3.612^{*}$ & $2.381^{* *}$ & $25.96^{*}$ & $494.57^{*}$ \\
(D) & 6 & $12.141^{*}$ & $0.492^{\text {ns }}$ & $14.88^{\text {ns }}$ & $1.305^{\text {ns }}$ & $0.557^{\text {ns }}$ & $7.30^{\text {ns }}$ & $232.94^{\text {ns }}$ \\
Cx D & 26 & 3.744 & 0.565 & 27.88 & 1.053 & 0.375 & 7.39 & 144.45 \\
Residue & & & & & & & & \\
\hline Average & & 19.35 & 10.05 & 55.64 & 15.48 & 2.86 & 10.90 & 48.70 \\
CV\% & 10.00 & 7.48 & 9.49 & 6.63 & 21.37 & 24.93 & 24.68 \\
\hline $1^{* * * *}$ and & & & & & & &
\end{tabular}

$\overline{1^{*},{ }^{* *}}$ and ${ }^{\mathrm{ns}}:$ Significant at $5 \%$, à $1 \%$ and non-significant, respectively, by the $\mathrm{F}$ Test.

Table 4. Average plant height at the beginning of flowering (APR1), in $\mathrm{cm}$, of seven densities (plants per linear meter) as a function of cultivars, under field conditions, Rio Paranaíba, MG.

\begin{tabular}{cccccccc}
\hline \multirow{2}{*}{ Cultivar } & \multicolumn{7}{c}{ Density } \\
\cline { 2 - 8 } & $\mathbf{8}$ & $\mathbf{1 0}$ & $\mathbf{1 2}$ & $\mathbf{1 4}$ & $\mathbf{1 6}$ & $\mathbf{1 8}$ & $\mathbf{2 0}$ \\
\hline TMG 7063 IPRO & $20.10 \mathrm{a}^{1}$ & $19.71 \mathrm{a}$ & $16.98 \mathrm{a}$ & $18.40 \mathrm{a}$ & $21.73 \mathrm{a}$ & $19.60 \mathrm{a}$ & $20.51 \mathrm{a}$ \\
BS 2606 IPRO & $17.41 \mathrm{a}$ & $21.30 \mathrm{a}$ & $19.91 \mathrm{a}$ & $20.83 \mathrm{a}$ & $16.10 \mathrm{~b}$ & $19.36 \mathrm{a}$ & $19.05 \mathrm{a}$ \\
\hline
\end{tabular}

${ }^{1}$ Averages followed by the same lower-case letter in the column do not differ at $5 \%$ probability using the Tukey Test.

It was not possible to establish a significant regression equation to describe the behavior of plant height (at R1) of the cultivars as a function of the seven densities (Figure 2); thus, plant height at flowering did not vary as a function of plant densities, both for the TMG 7063 IPRO and BS 2606 IPRO cultivars and presented an average value of 19.5 and $19.1 \mathrm{~cm}$, respectively. 
(A)

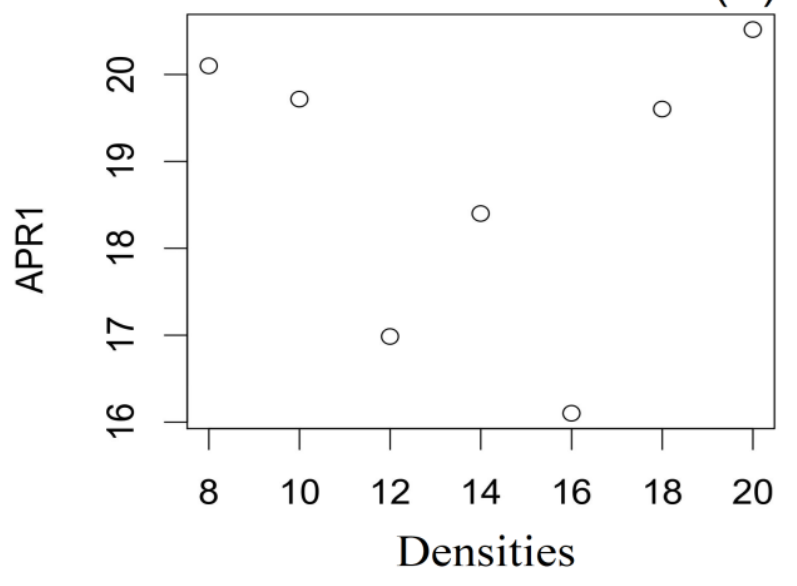

(B)

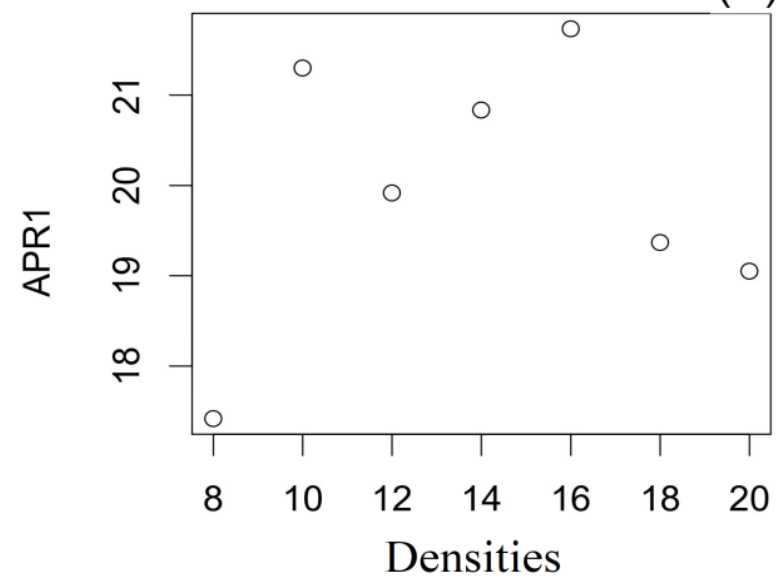

Figure 2. Behavior of plant height at R1 (APR1), in $\mathrm{cm}$, of cultivars as a function of the seven densities, in the field, Rio Paranaíba-MG. A: TMG 7063 IPRO; B: BS 2606 IPRO.

At the beginning of flowering the soybean crop is expected to be completely covering the soil, especially if the early material is fertilized and grown at spacing equal to or less than $0.50 \mathrm{~m}$ (Câmara, Piedade, Monteiro, \& Guerzoni, 1998). For this to be possible, the authors suggest that plant height at the beginning of flowering should be at least $50 \mathrm{~cm}$. When this minimum height is not reached th this phenological stage, the soybean crop has probably encountered problems related to management and/or the environment, such as late sowing time, low plant stand and competition with weeds (Câmara et al., 1998). In the present work, the plants were not subjected to any problem reported by Câmara et al. (1998); however, the flowering of soybean plants started at 36 days after emergence which corroborates the information of Instituto Goiano de Agricultura (IGA) (2018) for the cultivar TMG 7063 IPRO and of Câmara et al. (1998) with the cultivar IAS5 and the IDS421-E7 strain. Due to the rapid flowering, plants grew less in height and row closure was not observed, in other words, total soil coverage did not occur.

The height of insertion of the first pod, plant height, number of nodes and number of branches, evaluated at the R8 development stage, showed no significant effect for interaction cultivars vs densities. For number of nodes and number of branches, a significant effect was identified for the isolated factor of cultivars and when analyzing the effects of densities, significant results were obtained for all characters (Table 3 ).

In research conducted and evaluated in the state of Minas Gerais, similar results regarding the nonsignificant effect for interaction cultivars vs densities were reported by Bisinella and Simonetti (2017) for the parameters root and aerial part length and by Ribeiro et al. (2017) for plant height, number of pods, number of grains and number of grains per pod when studying the productive performance of soybean grown at different densities. As well as the present work, Ribeiro et al. (2017) selected soybean cultivars with similarity in maturity timing (similar maturity group among the assessed cultivars) and growth habit (indeterminate). Moreover, they reported the need to conduct and evaluate tests in different locations to measure the effects of cultivation sites.

The insertion height of the first pod showed within the studied interval a linear increase as a function of increasing sowing density (Figure 3, A). It is a result that corroborates with those found by Mauad, Silva, Almeida-Neto and Abreu (2010) and Ribeiro et al. (2017) in which they reported that for the insertion height of the first pod, it could be observed that the increase in the number of plants per hectare provides an increase in the insertion height.

This is an important variable to be considered in mechanized harvesting, because according to Sediyama, Teixeira and Reis (1999) the ideal height for the insertion of the first pod is between 10 and $12 \mathrm{~cm}$ so that there is no loss in harvesting on flat soils and, at least, $15 \mathrm{~cm}$ for soils with sloping topography, due to the height of the cutting platform. Thus, only after the density of 16 plants $\mathrm{m}^{-1}$ the ideal pod insertion height for mechanized harvesting occurred. Due to the lower growth of the plants and the lack of closure between the rows, it is believed that there was greater luminosity in the lower part of the plant, which resulted in the development of pods at a height lower than the one that was recommended by Sediyama et al. (1999).

The leaves of the lower canopy which receive most of the diffuse radiation are more photosynthetically efficient compared to leaves exposed to direct radiation (Souza, Rocha, Ribeiro, \& Souza 2010) and the 
photosynthetically active radiation in the lower and upper part of the plant were influenced by the crop densities (which ranged from 20 to 60 plants per square meter), with higher values in the lower densities (Petter et al., 2016). This reinforces that the lower plant height allowed light to penetrate the canopy, reaching the lower leaves, possibly favoring photosynthesis (Tancredi, Sediyama, Reis, Cecon, \& Teixeira, 2006) and cultivars that receive more light in the canopy have lower first pod insertion heights (Coelho, Benett, Arruda, Benett, \& Nascimento, 2019).

For final plant height, there was a positive linear effect with the increase in sowing density, that is, within the studied interval, for each plant unit that the density increases, there is an approximate increase of $1.6 \mathrm{~cm}$ in height (Figure 3, B). Komori, Hamawaki, Souza, Shigihara and Batista (2004) observed that in denser plantings there was greater plant growth in relation to less densely planted plants sown in the same period. Competition between plants occurs when there is less availability of photo-assimilates for vegetative growth in the form of branches, because they are preferentially destined for the growth of the main stem (Martins et al., 1999). Increased sowing density also increases intraspecific competition for water, nutrients and especially for light, resulting in plant etiolation (Mauad et al., 2010).

In the soybean culture, solar radiation is related to photosynthesis, main stem elongation, branching, leaf expansion, pod setting and biological fixation (Câmara, 2000). The higher plant height at the higher sowing densities was probably attributed to the search for factors necessary for its development, mainly light (Silva, Ferreira, Silva, Paiva, \& Sediyama, 2004). For this character associated with the cultivars analyzed in this work, further studies are suggested for a better understanding of the behavior since there was no total coverage of the soil by the plants.

(A)

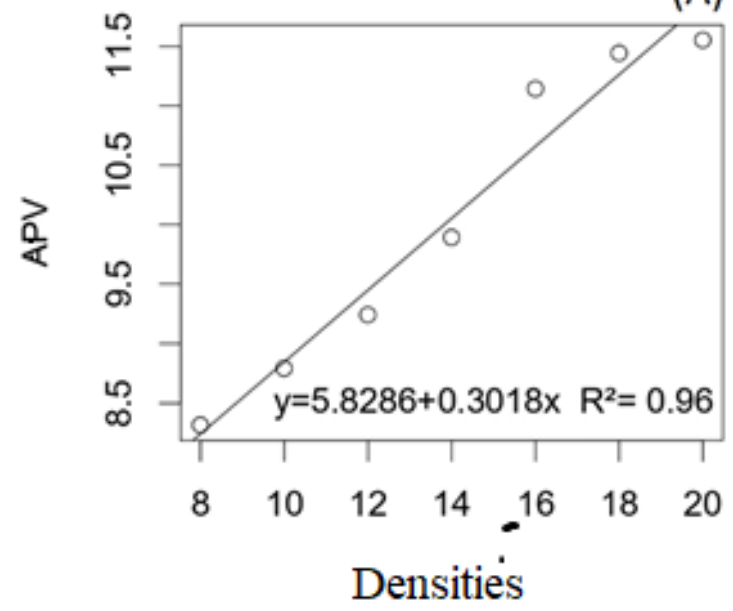

(B)

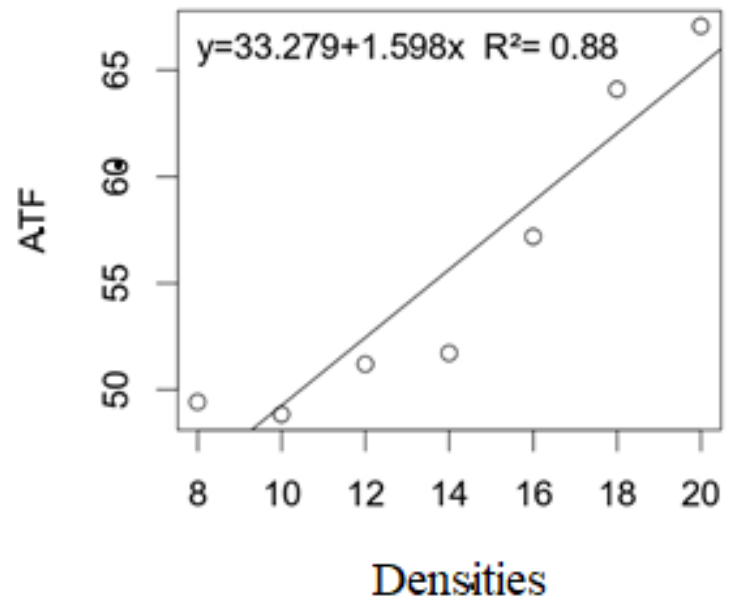

Figure 3. A: Insertion height of the first pod (APV), and B: Final plant height (ATF), in $\mathrm{cm}$, as a function of the seven densities, in the field, Rio Paranaíba, MG.

Tall plants or plants with very thin stems tend to become lodged more easily (Sediyama et al., 1999). This is important because generally the highest levels of lodging occur in cultivars that have the greatest heights (Mauad et al., 2010). For Rezende, Gris, Gomes, Tourino and Botrel (2004) populations greater than 400,000 plants per hectare provide higher rates of lodging. Carvalho, Resende, Andrade, Passos and Oliveira (2011) concluded that fertilization with the organic waste "poultry litter" increases plant height, but in high doses it favors the lodging of the plants. Under the conditions of the experiment, it was not observed plant lodging in any density. For the characters number of nodes and number of branches within the studied interval, a negative linear effect was observed with the increase in sowing density (Figure 4, A and B).

The reduction in the number of branches reduces the number of potential nodes and, consequently, the number of pods (Board \& Settimi, 1986) and the number of flowers per plant is determined by the number of flowers per node and the number of nodes per plant (Jiang \& Egli, 1993).

The morphophysiological characteristics such as the number of branches per plant and the number of fertile nodes, are related to the productive potential of the plant, since they represent a greater photosynthesizing and potentially productive surface through the number of sites for the appearance of flowers (Navarro-Júnior \& Costa, 2002). On the other hand, these authors reported that the number of branches may also represent additional demand that diverts photoassimilates that would otherwise be used in the fixation and production of reproductive structures. 
The cultivar TMG 7063 IPRO showed the highest average for number of nodes compared to BS 2606 IPRO, but in relation to the number of branches, the cultivar BS 2606 IPRO due to its high potential for budding obtained an average 1.4 times higher than the cultivar TMG 7063 IPRO (Table 5).

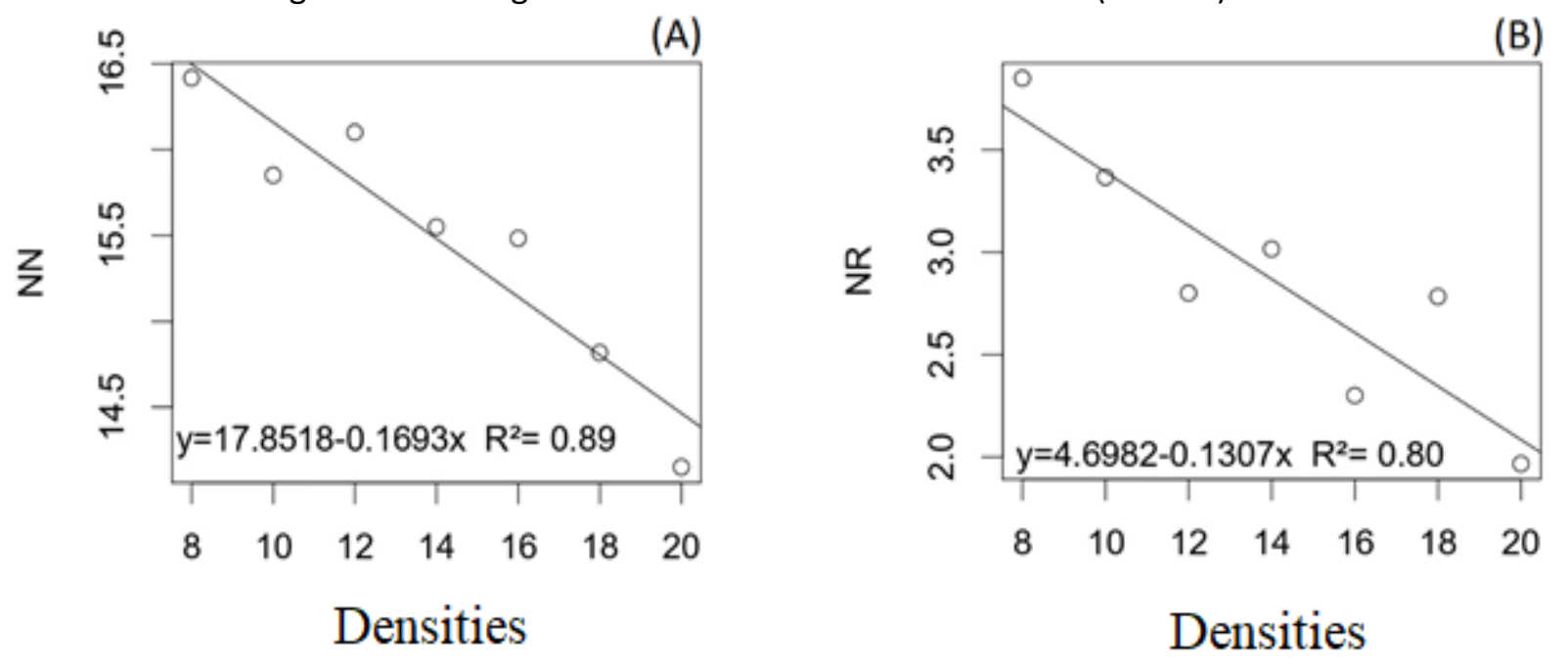

Figure 4. A: Number of nodes (NN) and B: Number of branches (NR), in $\mathrm{cm}$, as a function of plant densities (plants per meter), in the field, Rio Paranaíba, MG.

Table 5. Average number of nodes (NN) and branching (NB) obtained at the R8 development stage, as a function of two soybean cultivars (TMG 7063 IPRO and BS 2606 IPRO), under field conditions, Rio Paranaíba, MG.

\begin{tabular}{ccc}
\hline Cultivar & NN & NB \\
\hline TMG 7063 IPRO & $16.65 \mathrm{a}^{1}$ & $2.39 \mathrm{~b}$ \\
BS 2606 IPRO & $14.30 \mathrm{~b}$ & $3.34 \mathrm{a}$ \\
\hline
\end{tabular}

\begin{abstract}
${ }^{1}$ Averages followed by the same lower-case letter in the column do not differ at $5 \%$ probability using the Tukey Test.

The productivity per plant and productivity in bags per hectare showed a non-significant effect for cultivar vs density interaction. For isolated effect, the cultivar factor was significant for productivity in bags per hectare and for density both characters showed significant effects (Table 3 ). The productivity in sacks per hectare differed among cultivars (Table 6) and it was observed that the TMG 7063 IPRO cultivar presented a superior average compared to the BS 2606 IPRO cultivar, reaching a difference of 8 sacks per hectare in favor of TMG 7063 IPRO.
\end{abstract}

Table 6. Average productivity (in $60 \mathrm{~kg}$ bags hectare ${ }^{-1}$ ) obtained at harvest as a function of 2 soybean cultivars, under field conditions, Rio Paranaíba-MG.

\begin{tabular}{cc}
\hline Cultivar & Productivity (in 60 kg bags hectare $^{-1}$ ) \\
\hline TMG 7063 IPRO & $52.7 \mathrm{a}^{1}$ \\
BS 2606 IPRO & $44.7 \mathrm{~b}$
\end{tabular}

\footnotetext{
${ }^{1}$ Averages followed by the same lower-case letter in the column do not differ at $5 \%$ probability using the Tukey Test. Planting date: October 24, 2019 and experimental plots harvest date: February 14, 2020.
}

When analyzing the productivity per plant characteristic, it was observed that within the studied interval with increasing sowing density the characteristic has a negative linear effect and for each plant unit increased in density there is an approximate decrease of 0.41 grams per plant (Figure $5, A$ ). In plots with lower densities (10 plants per meter) the cultivar CAC-1 produced more than the plots with higher plant densities (22 plants per meter); this is because the genetic material was able to better express the productive potential of each 
plant to the point of overcoming the greater number of plants in the row (Tourino, Rezende, \& Salvador, 2002).

Soybean has great facility to emit branches mainly at lower plant densities, which can consequently produce more seeds (Sediyama, Pereira, Sediyama, \& Gomes, 1996) and it is expected that more compact plants, such as some cultivars with indeterminate growth type, could tolerate higher plant populations without reducing the productive potential of each individual, which in fact did not occur, in other words., the expected results were not observed (Garcia, Procópio, \& Balbinot-Júnior, 2017), which reinforces the results obtained in this work. Furthermore, they reported that the productive behavior of soybeans in reduced spacing proved to be variable, with strong influence of climatic conditions and genotypes.

(A)

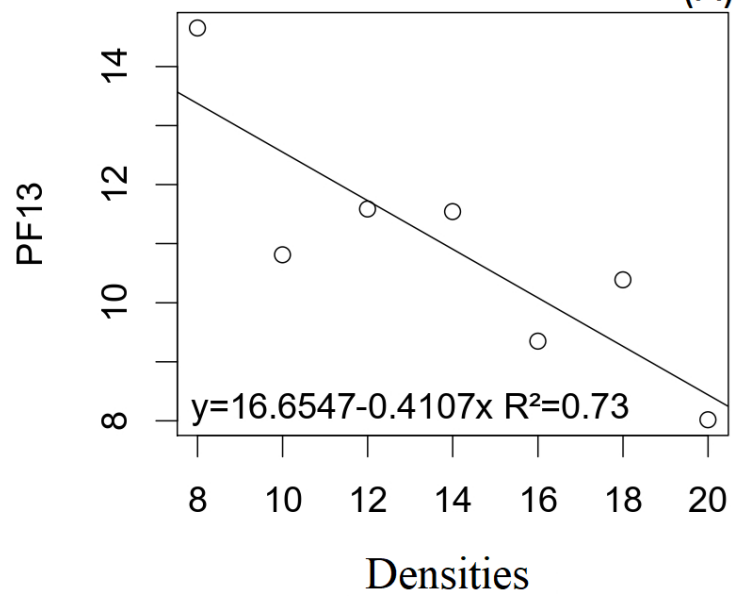

(B)

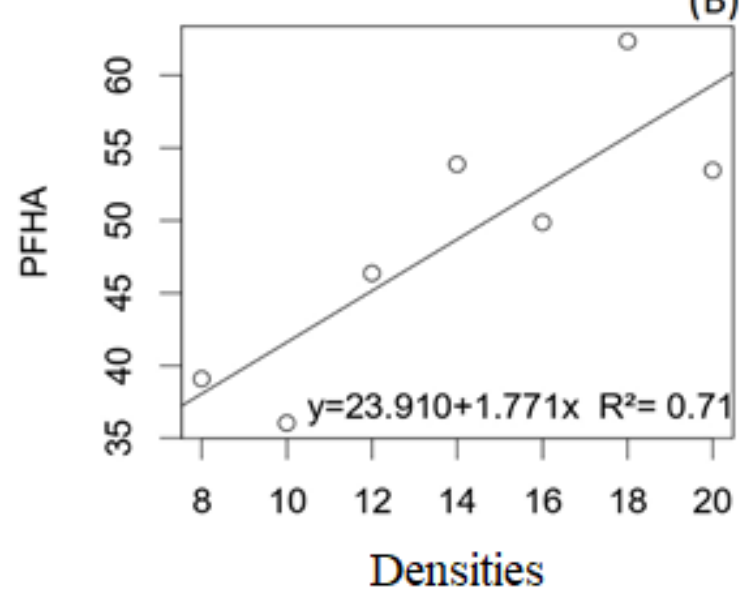

Figure 5. Final yield average per plant at 13\% (PF13), in $g(A)$, and final productivity per hectare (PFHA), in $60 \mathrm{~kg}$ bags hectare ${ }^{-1}(B)$, as a function of sowing density (plants per meter), in the field, Rio Paranaíba-MG.

The productivity in bags per hectare, by means of the average of the two cultivars, indicated an increasing linear effect as a function of the increase in sowing density, that is, an increase in the magnitude of 1.77 bags per hectare for each increase of one plant per linear meter, for the interval from 8 to 20 plants (16 to 40 plants per square meter) (Figure 5, B). This result corroborates with several authors. Peixoto et al. (2000) reported increased soybean productivity as a function of increased plant density only in the interim-harvest sowing season (planting on March 18) and that, within the interval studied, for each plant unit increased in density, there is an approximate increase of $10 \mathrm{~kg}$ of grains per hectare. Heiffig et al. (2006) noted the proportional growth of crop yield with increasing plant population. Cruz et al. (2016) reported increase in soybean yield as plant population is increased, i.e., in the present work, increase in sowing density provided increase in soybean grain yield regardless of the spatial arrangement between plants.

Plant densification can alter the leaf area and increase the percentage of interception of solar radiation and, consequently, the accumulation of dry matter (Porras, Cayón, \& Delgado, 1997). This is because optimizing the capacity of the plant to intercept solar radiation and or the accumulation of dry matter during its development determines the maximum yield of soybean, and the accumulation of dry matter is also dependent on other factors such as weather conditions, sowing date, genotype, soil fertility, plant population and row spacing (Wells, 1991; Wells, 1993). Furthermore, Petter et al. (2016) in an analysis of agronomic performance and through the dynamics of photosynthetically active radiation in the canopy, the densified soybean crop does not provide gains in productivity when the densification is greater than 40 plants per square meter.

\section{CONCLUSIONS}

The increase of the plant population resulted in greater first pod insertion height and final plant height, reduced number of nodes and branches and the average yield per hectare increased linearly.

The cultivars differed in the number of nodes and branching and the average yield per hectare was higher (52.7 kg bags per hectare) in the TMG 7063 IPRO cultivar. 


\section{ACKNOWLEDGEMENTS}

To Mr. Celso Yamanaka for providing the seeds that were used in this work.

\section{REFERENCES}

Argenta, G., Silva, P. R. F., \& Sangoi, L. (2001). Arranjo de plantas em milho: análise do estado-da-arte. Ciência Rural, 31(6), 1075-1084. https://doi.org/10.1590/s0103-84782001000600027

Balbinot-Junior, A. A. (2012). Acamamento de plantas na cultura da soja. Pesquisa Agropecuária Catarinense, 25(1), 40-42.

BASF (2021). Proteção de cultivos e sementes. https://agriculture.basf.com/br/pt/protecao-de-cultivos-esementes/produtos/soytech/SoyTech/BS-2606-IPRO.html

Bisinella, L. F., \& Simonetti, A. P. M. M. (2017). Plantio agrupado e convencional em duas cultivares de soja. Revista Cultivando $\quad 0 \quad$ Saber, http://177.53.200.37/index.php/cultivando/article/view/831

Board, J. E., \& Settimi, J. R. (1986). Photoperiod effect before and after flowering on branch development in determinate soybean 1. Agronomy Journal, 78(6), 995-1002. https://doi.org/10.2134/agronj1986.00021962007800060013x

Brachtvogel, E. L., Pereira, F. R. S., Cruz, S. C. S., \& Bicudo, S. J. (2009). Densidades populacionais de milho em arranjos espaciais convencional e equidistante entre plantas. Ciência Rural, 39 (8), 2334-2339. doi: https://doi.org/10.1590/S0103-84782009005000193

Câmara, G. M. S. (2000). Soja: tecnologia da produção II. Piracicaba, SP: Esalq/USP.

Câmara, G. M. S., Piedade, S. M. S., Monteiro, J. H., \& Guerzoni, R. A. (1998). Desempenho vegetativo e produtivo de cultivares e linhagens de soja de ciclo precoce no município de Piracicaba-SP. Scientia Agrícola, 55 (3). doi: https://doi.org/10.1590/S0103-90161998000300008

Carvalho, E. R., Rezende, P. M., Andrade, M. J. B., Passos, A. M. A., \& Oliveira, J. A. (2011). Fertilizante mineral e resíduo orgânico sobre características agronômicas da soja e nutrientes no solo. Revista Ciência Agronômica, 42(4), 930-939. https://doi.org/10.1590/s1806-66902011000400015

Coelho, P. H. M., Benett, K. S. S., Arruda, N., Benett, C. G. S., \& Nascimento, M. V. (2019). Crescimento e produtividade de dois cultivares de soja em função de doses de silício. Journal of Neotropical Agriculture, 6(3), 60-65. https://doi.org/10.32404/rean.v6i3.2602

COOXUPÉ - Cooperativa Regional de Cafeicultores em Guaxupé Ltda. (2020). Balanço hídrico diário. Estações meteorológicas Cooxupé. Guaxupé, MG: Cooxupé. Retrieved from http://sismet.cooxupe.com.br:9000/

Cox, W. J., \& Cherney, J. H. (2011). Growth and yield responses of soybean to row spacing and seeding rate. Agronomy Journal, 103(1), 123-128. https://doi.org/10.2134/agronj2010.0316

Cruz, S. C. S., Sena-Junior, D. G., Santos, D. M. A., Lunezzo, C. G. M. (2016). Cultivo de soja sob diferentes densidades de semeadura e arranjos espaciais. Revista de Agricultura Neotropical, 3(1), 1-6. Retrieved from https://periodicosonline.uems.br/index.php/agrineo/article/view/431

EMBRAPA - Empresa Brasileira de Pesquisa Agropecuária. (2013). Sistema brasileiro de classificação de solos. Brasília, DF: Embrapa.

Fehr, W. R., \& Caviness, C. E. (1977). Stage of soybean development(Special Report 80). Ames, IA: lowa State University.

Ferreira-Junior, J. A., Espindola, S. M. C. G., Gonçalves, D. A. R., \& Lopes, E. W. (2010). Avaliação de genótipos de soja em diferentes épocas de plantio e densidade de semeadura no município de Uberaba - MG. FAZU em Revista, 7, 13-21. 
Garcia, R. A., Procópio, S. O., \& Balbinot-Júnior, A. A. (2017). Produção de soja em diferentes arranjos espaciais de plantas no Paraná e Mato Grosso do Sul. Dourados, MS: Embrapa Agropecuária Oeste. Retrieved from https://www.embrapa.br/busca-de-publicacoes/-/publicacao/1082959/producao-desoja-em-diferentes-arranjos-espaciais-de-plantas-no-parana-e-em-mato-grosso-do-sul

Heiffig, L. S., Câmara, G. M. D. S., Marques, L. A., Pedroso, D. B., \& Piedade, S. M. D. S. (2006). Fechamento e índice de área foliar da cultura da soja. Bragantia, 65(2), 285-295. Retrieved from http://ref.scielo.org/hfzkwb

IGA - Instituto Goiano de Agricultura. (2018). Boletim técnico de resultados. Safra 2017-2018. Ano 1, edição 01. Montividiu, GO: IGA. Retrieved from http://iga-go.com.br/

Jiang, H., \& Egli, D. B. (1993). Shade induced changes in flower and pod number and flower and fruit abscission in soybean. Agronomy Journal, 85(2), 221-225. https://doi.org/10.2134/agronj1993.00021962008500020011x

Komori, E., Hamawaki, O. T., Souza, M. P., Shigihara, D., \& Batista, A. M. (2004). Influência da época de semeadura e população de plantas sobre características agronômicas na cultura da soja. Bioscience Journal, 20 (3), 13-19. doi: http://www.seer.ufu.br/index.php/biosciencejournal/article/view/6536

Lima, S. F., Alvarez, R. C. F., Theodoro, G. F., Bavaresco, M., \& Silva, K. S. (2012). Efeito da semeadura em linhas cruzadas sobre a produtividade de grãos e severidade da ferrugem asiática da soja. Bioscience Journal, 28 (6), 954-962. http://www.seer.ufu.br/index.php/biosciencejournal/article/view/13960

MAPA - Ministério da Agricultura, Pecuária e Abastecimento (2009). Regras para análise de sementes. Brasília, DF: MAPA.

Martins, M. C., Câmara, G. M. S., Peixoto, C. P., Marchiori, L. F. S., Leonardo, V., \& Mattiazzi, P. (1999). Épocas de semeadura, densidades de plantas e desempenho vegetativo de cultivares de soja. Scientia Agricola, 56(4), 851-858. https://doi.org/https://doi.org/10.1590/S0103-90161999000400012

Mauad, M., Silva, T. L. B., Almeida-Neto, A. I., \& Abreu, V. G. (2010). Influência da densidade de semeadura sobre características agronômicas na cultura da soja. Revista Agrarian, 3 (9), 175-181.

Navarro-Júnior, H. M., \& Costa, J. A. (2002). Contribuição relativa dos componentes do rendimento para produção de grãos em soja. Pesquisa Agropecuária Brasileira, 37(3), 269-274. https://doi.org/10.1590/s0100-204×2002000300006

Oda, M. C., Sediyama, T., Matsuo, E., Cruz, C. D., Barros, E. G., \& Ferreira, M. F. S. (2015). Phenotypic and molecular traits diversity in soybean launched in forty years of genetic breeding. Agronomy Science and Biotechnology, 1(1), 1. https://doi.org/10.33158/ASB.2015v1i1p1

Peixoto, C. P., Câmara, G. M. S., Martins, M. C., Marchiori, L. F. S., Guerzoni, R. A., \& Mattiazzi, P. (2000). Épocas de semeadura e densidade de plantas de soja: I. Componentes da produção e rendimento de grãos. Scientia Agricola, 57(1), 89-96. https://doi.org/https://doi.org/10.1590/S010390162000000100015

Petter, F. A., Silva, J. A., Zuffo, A. M., Andrade, F. R., Pacheco, L. P., \& de Almeida, F. A. (2016). Elevada densidade de semeadura aumenta a produtividade da soja? Respostas da radiação fotossinteticamente ativa. Bragantia, 75(2), 173-183. https://doi.org/10.1590/1678-4499.447

Pires, J. L. F., Costa, J. A., \& Thomas, A. L. (1998). Rendimento de grãos de soja influenciado pelo arranjo de plantas e níveis de adubação'. Pesquisa Agropecuária Gaúcha, 4(2), 183-188. Retrieved from http://www.fepagro.rs.gov.br/upload/1398911929_art_14.pdf

Porras, A. C., Cayón, G. D. Delgado, A. O. (1997). Comportamento fisiologico de genotipos de soja em diferentes arranjos de plantio. Acta Agronomica, 47(1), 1-15. 
Procópio, S. O., Balbinot-Junior, A. A., Debiasi, H., Franchini, J. C., \& Panison, F. (2013). Plantio cruzado na cultura da soja utilizando uma cultivar de hábito de crescimento indeterminado. Revista de Ciências Agrarias - Amazon Journal of Agricultural and Environmental Sciences, 56(4), 319-325. https://doi.org/10.4322/rca.2013.048

R Core Team (2019). R: A language and environment for statistical computing. Vienna, Austria: R Foundation for Statistical Computing. Retrieved from https://www.r-project.org/

Resende, P. M., Gris, C. F., Gomes, L. L., Tourino, M. C. C., \& Botrel, E. P. (2004). Efeito da semeadura a lanço e da população de plantas no rendimento de grãos e outras características da soja [Glycine Max (L.) Merrill]. Ciência e Agrotecnologia, 28 (3), 499-504. doi: http://dx.doi.org/10.1590/S141370542004000300003

Ribeiro, A. B. M., Bruzi, A. T., Zuffo, A. M., Zambiazzi, E. V., Soares, I. O., Vilela, N. J. D., ... Moreira, S. G. (2017). Productive performance of soybean cultivars grown in different plant densities. Ciência Rural, 47(7), 18. https://doi.org/10.1590/0103-8478cr20160928

Sediyama, T., Pereira, M. G., Sediyama, C. S., \& Gomes, J. L. L. (1996). Cultura da soja. Il parte. Viçosa, MG: Editora UFV.

Sediyama, T., Teixeira, R. C., \& Reis, M. S. (1999). Melhoramento da soja. In A. Borém (Ed.), Melhoramento de espécies cultivadas (pp. 478-533). Viçosa, MG: Editora UFV.

Silva, A. C., Ferreira, L. R., Silva, A. A., Paiva, T. W. B., \& Sediyama, C. S. (2004). Efeitos de doses reduzidas de fluazifop-p-butil no consórcio entre soja e Brachiaria brizantha. Planta daninha. 22 (3), 429-435. https://doi.org/10.1590/S0100-83582004000300013

Silva, W. B., Petter, F. A., Lima, L. B., \& Andrade, F. R. (2013). Desenvolvimento inicial de Urochloa ruziziensis e desempenho agronômico da soja em diferentes arranjos espaciais no cerrado Mato-Grossense. Bragantia, 72(2), 146-153. https://doi.org/10.1590/S0006-87052013000200006

Soares, M. M., Sediyama, T., \& Matsuo, É. (2020). Efficiency and responsiveness of using phosphorus and molecular diversity among soybean cultivars. Agronomy Science and Biotechnology, 6, 1-11. https://doi.org/10.33158/asb.r108.v6.2020

Souza, P. J. O. P., Rocha, E. J. P., Ribeiro, A., \& Souza, E. B. (2010). Radiation balance in a soybean ecosystem in the Amazon. Revista Ciencia Agronomica, 41(4), 582-592. https://doi.org/10.1590/s180666902010000400010

Tancredi, D. F., Sediyama, T., Reis, S. M., Cecon, R. P., \& Teixeira, C. R. (2006). Effect of Removal of Apical Meristem on Soybean Plants Growth and development in greenhouse conditions. Bioscience Journal, 22(2), 53-60. http://www.seer.ufu.br/index.php/biosciencejournal/article/view/6716

Tavares, L. A. F., Correia, T. P. S., Sousa, S. F. G., Riquetti, N. B., \& Silva, P. R. A. (2019). Viabilidade econômica da semeadura de soja em diferentes arranjos espaciais de plantas. Energia na Agricultura, 34 (2), 171179. https://doi.org/10.17224/EnergAgric.2019v34n2p171-179

TMG - Tropical Melhoramento \& Genética S.A. (2021). Cultivar de Soja. Londrina, PR: TMG. Retrieved from https://www.tmg.agr.br/ptbr/cultivar/tmg-7063-ipro

Tourino, M. C. C., Rezende, P. M., \& Salvador, N. (2002). Row spacing, plant density and intrarow plant spacing uniformity effect on soybean yield and agronomic characteristics. Pesquisa Agropecuaria Brasileira, 37(8), 1071-1077. https://doi.org/10.1590/s0100-204×2002000800004

Vazquez, G. H., Carvalho, N. M., \& Borba, M. M. Z. (2008). Redução na população de plantas sobre a produtividade e a qualidade fisiologica da semente de soja. Revista Brasileira de Sementes, 30(2), 1-11.

Wells, R. (1991). Soybean growth response to plant density: relationships among canopy photosynthesis, leaf area, and light interception. Crop Science, 31(3), 755-761. https://doi.org/10.2135/cropsci1991.0011183×003100030044x 
Wells, R. (1993). Dynamics of soybean growth in variable planting patterns. Agronomy Journal, 85(1), 44-48. https://doi.org/10.2134/agronj1993.00021962008500010009x

Received: April 26, 2021.

Accepted: May 21, 2021.

Published: July 29, 2021.

English by: André Luis Miyagaki. 